\title{
Teenagers and ICT usage: analysis of its emotional, academic, and social effects
}

\author{
Ignacio González López \\ ignacio.gonzalez@uco.es \\ Universidad de Córdoba, Spain \\ Belén Quintero Ordóñez \\ bquintero@uco.es \\ Universidad de Córdoba, Spain \\ Eloísa Reche Urbano \\ fe1reure@uco.es \\ Universidad de Córdoba, Spain \\ Juan Fuentes Esparrell \\ fuentese@ugr.es \\ Universidad de Granada, Spain
}

\begin{abstract}
This study aims to determine the perceptions families have about their children's use of Information and Communication Technologies, identifying usage habits and their effects on the management of emotions, within the academic and social settings. The study was conducted with a total of 253 families from throughout Spain, whose children are between the ages of 14 and 16 and are attending compulsory secondary education. To this end, a crosssectional non-experimental study was carried out by means of a survey. The families surveyed indicate that their children use technology for five hours a day, the mobile phone being the most widely used device, and that this directly affects their levels of irritability and frustration when usage is limited, but does not cause adverse effects in academic and social settings.
\end{abstract}

\section{Key words:}

ICT; usage habits; emotional management; social setting; academic setting 


\section{Introduction}

Information and Communication Technologies (ICT) are prevalent in our lives, both personal and professional, to the extent that sometimes we are unable to do certain tasks without them. Their prominence in today's society is generating risks and problems that have not been considered thus far (Pedrero-Pérez, 2018).

This incursion of technology into our everyday lives has brought about changes in many common practices, such as the way in which communication takes place between colleagues, students, managers, etc; access to and the creation of digital resources; social participation through the use of social media; and academic literacy, among others, promoting new relational configurations in the academic and personal arenas (Hernández, López and Salado, 2020).

In this regard, Spain's National Institute for Statistics (INE, 2020) considers that the use of technologies by minors is widespread in households, especially the use of the Internet $(94.5 \%)$, followed by the use of computers (91.5\%). Another booming technology is the mobile phone, and $69.5 \%$ of the population aged 10 to 15 has one of these devices. Looking at internet use in recent months, it is universal, reaching levels of $99.8 \%$ among young people aged 16 to 24 .

The increase in the use of ICTs among the adolescent population lies in the ease of obtaining a rapid response to their demands, having immediate rewards for their actions, and the possibility of interacting with many people in a very small setting (Echeburúa, 2012). In addition, Carbonell and Oberts (2015) argue that, within the youth population, access to social media allows them to build their social identity, due to the trend of hyperconnectivity as a vehicle to relate to their peers.

This social change caused by the rise of ICT among the adolescent population has sparked the development of numerous studies and research within the scientific community to determine the consequences of ICT usage.

Oliva et al. (2012) argue that the positive aspects include the enhancement of spatial and visual cognition as a result of playing videogames as a child. Similarly, they have identified a relationship between home computer use and performance at school, where the use of the Internet to search for information is an important element. Finally, they show that ICTs facilitate the maintenance of social relations through the use of mobile phones or social media.

As for the risks and problematic use of technologies among the adolescent population, De La Fuente (2011) notes that not all people who use ICTs will develop an addiction, and not all usage of them will be considered problematic. Problematic usage can be understood as spending uninterrupted periods of time in the virtual sphere to such an extent that it clashes with the normal development of a person's daily life, leading to the neglect of academic, working, and personal activities (Puerta-Cortés and Carbonell, 2014). Similarly, the problematic use of technology can cause symptoms related to psychological distress or social deterioration (Sánchez-Carbonell et al., 2008). Specifically, among the adolescent population, such problematic usage can lead to manifestations of juvenile social isolation syndrome, characterised by antisocial and avoidance behaviour, rejecting any type of communication, and focusing their life on the use of the Internet and new technologies (De la Calle and Muñoz, 2018).

The most common traits of someone who displays a problematic usage of ICT, regardless of the device used, are difficulties coping and solving problems, impulse control, difficulty dealing with unpleasant stimuli such as pain or sadness, and the need to seek out strong feelings (Cia, 2013).

In the case of the teenage population, all problems associated with the inappropriate use of technologies revolve around aspects of their social and academic settings. Specifically, Espinel-Rubio, Hernández-Suárez and Rojas-Suárez (2020A, p. 100) argue that "technology intervenes in individuals, especially children and adolescents, in the development of their personality, as well as in: 
interaction, communication, participation, autonomy, self-esteem, and in the socio-relational field". Along these lines, Diaz-Vicario, Mercader and Gairín (2019) confirm that ICTs can negatively affect not only the socio-relational dimension, but also the social and family environment, as well as leisure and recreation. In this respect, in the social, socio-relational, or peer-group environment, according to Sabater and Bingen (2015), technologies are considered by adolescents to be a very powerful tool for socialisation. These socially maladaptive behaviours, derived from the use of technologies, can be transformed by strengthening positive self-esteem, working to develop adequate social and communication skills, promoting attributional style, problem solving capacity, coping with emotions, and managing stress (Echeburúa and Requesens, 2012).

With regard to ICT in the school setting, "not only do they build the skills of adolescents towards Internet access in the search for information as a basic notion, but they encompass the use of social media and the management of personal networks" (Espinel-Rubio, Hernández-Suárez and Rojas-Suárez, 2020A, p. 101). In this arena, inappropriate use of ICTs by the adolescent population may lead to risky behaviours (Garaigordobil, 2011), such as access to age-inappropriate content, loss of privacy (by making parts of their personal life publicly visible), bullying, etc. (Garrote-Rojas, Jiménez-Fernández, Gómez-Barreto, 2018). In addition, Haddon and Vicent (2014) confirm that ICTs can create distractions in the classroom and lead to a decrease in study time.

Díaz-Vicar, Mercader and Gairín (2019, p. 8) highlight the effects of problematic use of ICT within the family, indicating that "the emergence of family conflicts is evident because of excessive use and/or use of ICTs while family activities are being carried out", noting that adolescents identify problematic uses in their peer group without being aware of their own risk behaviours.

Along these lines, Torrecillas-Lacave, Vázquez-Barrio and Monteagudo-Barandalla (2017) establish that, within the family, ICTs are regarded with ambivalence. On the one hand, they generate conflict within the family, seeing that the personal autonomous use of devices leads to isolation and individualism among children and teenagers. On the other hand, there are family settings that ensure that the use of technologies among adolescents promotes family cohesion, enabling immediate intra-family communication.

In short, the use of ICTs among the adolescent population is giving rise to difficulties and inappropriate usage that go unnoticed on a personal level, so the fields of reference - school or academic setting, family and social environments - must be in tune to observe inappropriate behaviour and start to develop actions that modify these behaviours and link technologies with appropriate and responsible use.

\section{Methodology}

The general aim of this study has been to describe the effects of the prevalent use of ICT on the management of emotions among students aged between 14 and 16 from the perspective of their families. The specific objectives are: A) to analyse the influence of ICT in the social setting in which students develop their interactions; b) to assess the influence of ICT usage in the academic setting in which adolescents study; and c) to define the ICT usage habits of Secondary School students.

The research design is based on a cross-sectional descriptive non-experimental methodology, the purpose of which is to gain a comprehensive understanding of a specific reality (Neuman, 2014). To this end, the survey technique was used, since it responds to problems in exploratory terms and with regard to relationships between variables, which ensures the rigour of the information collected (Hernández, Fernández and Baptista, 2014).

A bespoke questionnaire was designed, encompassing a total of 60 items, distributed into five ana- 
lytical dimensions, to collect data: identification details, usage habits, emotional management, the influence of ICTs on the social setting, and the influence of ICTs on the academic setting. The format is a five-point assessment scale ( $1=$ not at all, $5=$ a lot), with the exception of one element (amount of time students spend using ICTs per day), where 1 signifies less than 1 hour and 5 means more than 6 hours, eight items relative to students' preference regarding accompaniment when using ICTs, with a response range of three points, 1 being the highest priority and 3 being the lowest, and one free item referring to the family's perception about the student's use of ICTs. The final design stage involved theoretical construction that was subjected to expert evaluation, achieving an Aiken's $V$ consensus index among the 11 participants above .50 in all its elements, in addition to a pilot study, where the contributions of 21 family members resulted in a Cronbach Alpha coefficient of .851 and $100 \%$ discriminatory power of the scale items.

A total of 253 family members of compulsory secondary education students from the 2019-2020 academic year participated in the study. The mean age of these family members was 48.28 years of age ( $S D=6.982)$, and women made up the majority of the sample $(66 \%$ of women vs. $34 \%$ of men) This group was selected by means of intentional, non-probabilistic sampling. The relationship to the students was as follows: $62.1 \%$ mothers, $27.3 \%$ fathers, and the remaining $10.7 \%$ corresponding to other members of the family environment such as grandparents, uncles and aunts, common-law partners, etc. They come from 12 regions of the country, mainly Andalusia $(35.6 \%)$, Castilla y Leon $(15.4 \%)$ and the region of Valencia $(13.0 \%)$. Other places of residence were the Canary Islands (9.1\%), Murcia (5.9\%), Madrid (4.3\%), Galicia $(4.0 \%)$, Balearic Islands $(3.6 \%)$, Catalonia (3.6\%), Asturias (2.0\%), Melilla (2.0\%) and La Rioja (1.6\%).

The information collected was ordered and statistically analysed using the SPSS programme version 25.

\section{Results}

Defining the ICT usage habits of these students based on the perceptions of their families, mainly mothers and fathers, involves exploring the amount of time devoted to technology-related activities every day, and it is important to know the preferred device, preference regarding accompaniment when using technology, and what these activities actually are.

An initial exploration of the amount of time devoted to using ICTs every day reveals that, for the most part, families estimate that their children spend between 3 and 4 hours using technology every day $(31.6 \%)$, with $48.6 \%$ spending more than 5 hours a day on activities carried out using devices and technological tools (see table 1). However, this perception varies depending on whether the father or the mother provides this information. In general terms, women feel that their children spend too much time per day using ICTs, identifying more than 5 hours in $48.6 \%$ cases (chi square $=11.419 ; \mathrm{p}=.022$ )

\begin{tabular}{|l|r|r|r|r|r|r|}
\hline \multirow{2}{*}{ Time spent per day } & \multicolumn{2}{|c|}{ Total } & \multicolumn{2}{c|}{ Men } & \multicolumn{2}{c|}{ Women } \\
\cline { 2 - 7 } & \multicolumn{1}{|c|}{$\mathrm{f}$} & \multicolumn{1}{c|}{$\%$} & \multicolumn{1}{c|}{$\mathrm{f}$} & \multicolumn{1}{c|}{$\%$} & \multicolumn{1}{c|}{$\mathrm{f}$} & \multicolumn{1}{c|}{$\%$} \\
\hline Less than 1 hour & 9 & 3.6 & 0 & 0.0 & 9 & 5.5 \\
\hline 1 to 2 hours & 40 & 16.2 & 12 & 14.5 & 28 & 17.1 \\
\hline 3 to 4 hours & 78 & 31.6 & 34 & 41.0 & 44 & 26.8 \\
\hline 5 to 6 hours & 64 & 25.9 & 24 & 28.9 & 40 & 24.4 \\
\hline
\end{tabular}




\begin{tabular}{|l|r|r|r|r|r|r|}
\hline More than 6 hours & 56 & 22.7 & 13 & 15.7 & 43 & 26.2 \\
\hline Total & 247 & $\begin{array}{r}100 . \\
0\end{array}$ & 83 & $\begin{array}{r}100 . \\
0\end{array}$ & 164 & $\begin{array}{r}100 . \\
0\end{array}$ \\
\hline
\end{tabular}

Table 1. Time students spend using ICTs on a daily basis

The technological device most used by students, as observed by their relatives (see table 2 ), is the mobile phone (mean $=3.97, \mathrm{SD}=1.197)$, followed by the computer ( mean $=2.33, \mathrm{SD}=1.301$ ) and the Smart-TV (mean $=2.23, \mathrm{SD}=1.203$ ). Tools such as smartwatches or eBooks are hardly used.

\begin{tabular}{|c|c|c|}
\hline Device & $\begin{array}{c}\text { Mea } \\
\mathrm{n}\end{array}$ & SD \\
\hline Mobile phone & 3.97 & $\begin{array}{r}1.19 \\
7\end{array}$ \\
\hline Computer & 2.33 & $\begin{array}{r}1.30 \\
1\end{array}$ \\
\hline Smart-TV & 2.23 & $\begin{array}{r}1.20 \\
3\end{array}$ \\
\hline Games console & 1.92 & $\begin{array}{r}1.23 \\
8\end{array}$ \\
\hline Tablet & 1.59 & $\begin{array}{r}1.12 \\
1\end{array}$ \\
\hline SmartWatch & 1.08 & $\begin{array}{r}0.47 \\
3\end{array}$ \\
\hline E-book & 1.03 & $\begin{array}{r}0.28 \\
7\end{array}$ \\
\hline
\end{tabular}

Table 2. Type of device used by students

In the opinion of their families (see table 3 ), these students largely prefer to use ICT individually $(70.3 \%)$, with their peer group being a medium preference for usage $(53.7 \%)$, and time spent with classmates down in last place (29.3\%).

\begin{tabular}{|l|r|r|r|r|r|r|}
\hline \multirow{2}{*}{$\begin{array}{l}\text { Preference regarding } \\
\text { accompaniment }\end{array}$} & \multicolumn{2}{|c|}{$\begin{array}{c}\text { High } \\
\text { priority }\end{array}$} & \multicolumn{2}{c|}{$\begin{array}{c}\text { Medium pri- } \\
\text { ority }\end{array}$} & \multicolumn{2}{c|}{$\begin{array}{c}\text { Low } \\
\text { priority }\end{array}$} \\
\cline { 2 - 7 } & \multicolumn{1}{c|}{$f$} & \multicolumn{1}{c|}{$\%$} & \multicolumn{1}{c|}{$f$} & \multicolumn{1}{c|}{$\%$} & \multicolumn{1}{c|}{$f$} & \multicolumn{1}{c|}{$\%$} \\
\hline Alone & 178 & 70.3 & 29 & 11.5 & 9 & 3.5 \\
\hline With friend(s) & 51 & 20.1 & 136 & 53.7 & 13 & 5.1 \\
\hline With classmate(s) & 2 & 0.8 & 12 & 4.7 & 74 & 29.2 \\
\hline With the whole family & 3 & 1.2 & 14 & 5.5 & 33 & 13.0 \\
\hline $\begin{array}{l}\text { With their father- } \\
\text { guardian }\end{array}$ & 0 & 0.0 & 2 & 0.8 & 11 & 4.3 \\
\hline $\begin{array}{l}\text { With their mother- } \\
\text { guardian }\end{array}$ & 0 & 0.0 & 9 & 3.5 & 15 & 5.9 \\
\hline
\end{tabular}




\begin{tabular}{|l|r|r|r|r|r|r|}
\hline With their sibling(s) & 3 & 1.2 & 8 & 3.2 & 28 & 11.1 \\
\hline With my partner & 2 & 0.8 & 13 & 5.1 & 20 & 8.0 \\
\hline
\end{tabular}

Table 3. Students' preference in terms of accompaniment when using ICTs Note: The percentage was calculated based on the value $\mathrm{N}=253$

The different activities that the families observe in these students, where ICTs are the main element of interaction, include instant messaging (mean $=4.50, \mathrm{SD}=1.774$ ), engaging with or watching Social Media channels (mean $=3.53, \mathrm{SD}=1.202$ ) and listening to music on the Web (mean $=3.46, \mathrm{SD}=1.276$ ), with no activity requiring economic investment such as gambling or shopping online or consuming sex on the web being relevant (see table 4).

\begin{tabular}{|l|r|r|}
\hline \multicolumn{1}{|c|}{ Activities carried out with the use of ICTs } & Mean & \multicolumn{1}{c|}{ SD } \\
\hline Participate with comments on broadcast channels & 2.50 & 1.327 \\
\hline $\begin{array}{l}\text { Have an account on a broadcast channel or upload } \\
\text { videos to the Web }\end{array}$ & 1.53 & 0.977 \\
\hline Engage with or look at Social Media channels & 3.53 & 1.202 \\
\hline Instant messaging & 4.50 & 1.774 \\
\hline Play online via games console & 2.06 & 1.359 \\
\hline Tendency to play online through other devices & 2.26 & 1.400 \\
\hline Tendency to watch series and movie channels & 2.98 & 1.219 \\
\hline Search the Web for information & 3.16 & 1.092 \\
\hline Listen to music on the Web & 3.46 & 1.276 \\
\hline Online gambling & 1.17 & 0.657 \\
\hline Shop online & 1.30 & 0.710 \\
\hline Consume sex online & 1.41 & 0.915 \\
\hline
\end{tabular}

Table 4. Activities carried out with the use of ICTs

These consumption habits have a direct impact on the management of their emotions (see table 5 ), which in the opinion of mothers and fathers is summarised in the appearance of irritability when it comes to controlling the number of hours of technology usage (mean=3.65, SD=1.229), rather than in manifestations of aggressiveness, or in the feeling of fear of being without their devices (mean=3.20, SD=1.464). Families feel that these students are not using technologies because they are afraid of feeling socially excluded or are afraid to lose control of what is going on around them, as they do not seek to relate to other people through their use.

\begin{tabular}{|l|r|r|r|r|r|r|r|r|}
\hline \multirow{2}{*}{$\begin{array}{c}\text { The influence of ICTs } \\
\text { on emotional mana- } \\
\text { gement }\end{array}$} & \multicolumn{2}{|c|}{ Total } & \multicolumn{2}{c|}{ Men } & \multicolumn{2}{c|}{ Women } & \multicolumn{2}{c|}{$\begin{array}{c}\text { Difference of } \\
\text { means }\end{array}$} \\
\cline { 2 - 10 } & $\begin{array}{r}\text { Mea } \\
\mathrm{n}\end{array}$ & SD & $\begin{array}{r}\text { Mea } \\
\mathrm{n}\end{array}$ & SD & $\begin{array}{r}\text { Mea } \\
\mathrm{n}\end{array}$ & SD & $\mathrm{t}$ & $\mathrm{p}$ \\
\hline $\begin{array}{l}\text { Use of technologies } \\
\text { because they help } \\
\text { them relate to others }\end{array}$ & 2.80 & $\begin{array}{r}1.33 \\
4\end{array}$ & 2.79 & $\begin{array}{r}1.32 \\
9\end{array}$ & 2.81 & $\begin{array}{r}1.34 \\
1\end{array}$ & $\begin{array}{r}-0.1 \\
14\end{array}$ & .919 \\
\hline
\end{tabular}




\begin{tabular}{|c|c|c|c|c|c|c|c|c|}
\hline $\begin{array}{l}\text { Use of technologies } \\
\text { through fear of being } \\
\text { socially excluded }\end{array}$ & 2.28 & $\begin{array}{r}1.35 \\
3\end{array}$ & 2.20 & $\begin{array}{r}1.30 \\
7\end{array}$ & 2.33 & $\begin{array}{r}1.37 \\
8\end{array}$ & $\begin{array}{r}-0.7 \\
01\end{array}$ & .484 \\
\hline $\begin{array}{l}\text { Irritability when con- } \\
\text { trolling hours of usage }\end{array}$ & 3.65 & $\begin{array}{r}1.22 \\
9\end{array}$ & 4.25 & $\begin{array}{r}1.48 \\
1\end{array}$ & 3.34 & $\begin{array}{r}1.46 \\
2\end{array}$ & $\begin{array}{r}1.09 \\
6\end{array}$ & .274 \\
\hline $\begin{array}{l}\text { Manifestation of ag- } \\
\text { gressiveness when } \\
\text { number of hours of } \\
\text { technology usage are } \\
\text { controlled }\end{array}$ & 2.74 & $\begin{array}{r}1.54 \\
0\end{array}$ & 2.67 & $\begin{array}{r}1.43 \\
4\end{array}$ & 2.78 & $\begin{array}{r}1.59 \\
4\end{array}$ & $\begin{array}{r}-0.5 \\
28\end{array}$ & .598 \\
\hline $\begin{array}{l}\text { Fear of being without } \\
\text { devices }\end{array}$ & 3.20 & $\begin{array}{r}1.46 \\
4\end{array}$ & 2.91 & $\begin{array}{r}1.42 \\
8\end{array}$ & 3.35 & $\begin{array}{r}1.46 \\
4\end{array}$ & $\begin{array}{r}-2.3 \\
11\end{array}$ & .022 \\
\hline $\begin{array}{l}\text { Use of technologies } \\
\text { due to fear of losing } \\
\text { control what is happe- } \\
\text { ning around them }\end{array}$ & 2.29 & $\begin{array}{r}1.31 \\
1\end{array}$ & 2.19 & $\begin{array}{r}1.10 \\
3\end{array}$ & 2.34 & $\begin{array}{r}1.41 \\
6\end{array}$ & $\begin{array}{r}-0.8 \\
97\end{array}$ & .371 \\
\hline
\end{tabular}

Table 5. The influence of ICTs on emotional management

When seeking to establish a differentiating element in perceptions of the emotional impact of ICT consumption depending on whether the information was provided by men or women, the application of a $t$-test for independent samples (n.s. $=.05)$ showed only that mothers observed a greater tendency in their children, unlike fathers, towards fear of being without their devices $(t=-2.311$, $\mathrm{p}=.022$ ).

On the other hand, in reference to the assessment by family members of the degree to which the use of ICTs affects the students' social setting, the data in Table 6 indicate that, in their view, ICT usage is not harmful to their interpersonal relationships, since these students do not enjoy virtual relationships more than real world ones (mean $=2.08, \mathrm{SD}=1.246$ ), they do not show interest in them (mean=2.21, SD=1.283) or spend time in establishing them (mean=2.32, mean=1.389). Also, these families observe that students do not readily show their emotions in the virtual world (mean=2.38, SD=1.389), expressing and conversing more easily and fluently in the physical world. These opinions are similar regardless of whether the responses are provided by male or female relatives.

\begin{tabular}{|l|r|r|r|r|r|r|r|r|}
\hline \multirow{2}{*}{$\begin{array}{c}\text { The influence of ICTs in } \\
\text { the social setting }\end{array}$} & \multicolumn{2}{|c|}{ Total } & \multicolumn{2}{c|}{ Men } & \multicolumn{2}{c|}{ Women } & \multicolumn{2}{|c|}{$\begin{array}{r}\text { Difference of } \\
\text { means }\end{array}$} \\
\cline { 2 - 9 } & $\begin{array}{r}\text { Mea } \\
\mathrm{n}\end{array}$ & $\mathrm{SD}$ & $\begin{array}{r}\text { Mea } \\
\mathrm{n}\end{array}$ & $\mathrm{SD}$ & $\begin{array}{r}\text { Mea } \\
\mathrm{n}\end{array}$ & $\mathrm{SD}$ & $\mathrm{t}$ & $\mathrm{p}$ \\
\hline $\begin{array}{l}\text { Shows more interest in } \\
\text { virtual relationships } \\
\text { than in real world ones }\end{array}$ & 2.21 & $\begin{array}{r}1.28 \\
3\end{array}$ & 2.34 & $\begin{array}{r}2.34 \\
3\end{array}$ & 2.14 & $\begin{array}{r}1.24 \\
9\end{array}$ & $\begin{array}{r}1.17 \\
8\end{array}$ & .240 \\
\hline $\begin{array}{l}\text { Enjoys virtual relati- } \\
\text { onships more than real } \\
\text { world ones }\end{array}$ & 2.08 & $\begin{array}{r}1.24 \\
6\end{array}$ & 2.20 & $\begin{array}{r}1.29 \\
1\end{array}$ & 2.01 & $\begin{array}{r}1.22 \\
1\end{array}$ & $\begin{array}{r}1.11 \\
5\end{array}$ & .266 \\
\hline
\end{tabular}




\begin{tabular}{|l|r|r|r|r|r|r|r|r|}
\hline $\begin{array}{l}\text { Invests more time in } \\
\text { virtual relationships } \\
\text { than in real world ones }\end{array}$ & 2.32 & $\begin{array}{r}1.31 \\
4\end{array}$ & 2.44 & $\begin{array}{r}1.29 \\
8\end{array}$ & 2.44 & $\begin{array}{r}1.29 \\
8\end{array}$ & $\begin{array}{r}1.09 \\
7\end{array}$ & .274 \\
\hline $\begin{array}{l}\text { Shows their emotions } \\
\text { more easily in the vir- } \\
\text { tual world than in the } \\
\text { physical world }\end{array}$ & 2.38 & $\begin{array}{r}1.38 \\
9\end{array}$ & 2.51 & $\begin{array}{r}1.37 \\
4\end{array}$ & 2.31 & $\begin{array}{r}1.39 \\
6\end{array}$ & $\begin{array}{r}1.05 \\
2\end{array}$ & .294 \\
\hline $\begin{array}{l}\text { Expresses what they } \\
\text { think more easily in } \\
\text { the virtual world than } \\
\text { in the physical world }\end{array}$ & 2.46 & $\begin{array}{r}1.36 \\
9\end{array}$ & 2.54 & $\begin{array}{r}1.35 \\
0\end{array}$ & 2.42 & 1.38 & 0.64 & .519 \\
\hline $\begin{array}{l}\text { Pays more attention to } \\
\text { virtual conversations } \\
\text { than those in the phy- } \\
\text { sical world }\end{array}$ & 2.43 & 1.33 & 2.55 & 1.35 & 2.36 & 1.32 & 1.07 & 7 \\
\hline
\end{tabular}

Table 6. The influence of ICTs in the social setting

As in the previous case, these families also evaluated the influence of ICT usage on their children's academic setting. Based on the data in Table 7, it appears that ICT usage does not affect school activities, especially as regards the establishment of relationships with their classmates (mean=1.90, SD = 1.178), which are significant, or in terms of skipping class (mean=2.01, $\mathrm{SD}=1.374$ ). It might be significant to note that the daily use of ICTs is affecting them in terms of concentrating on their studies (mean $=2.81, \mathrm{SD}=1.514$ ), which affects the loss of desire to study (mean=2.72, SD=1.585) and, to a lesser extent, failing to do homework (mean=2.63, SD=1.470), which can lead to an overall decline in their grades (mean=2.59, SD =1.587). As in the previous dimension, men and women express the same opinions.

\begin{tabular}{|c|c|c|c|c|c|c|c|c|}
\hline \multirow{2}{*}{$\begin{array}{l}\text { The influence of ICT in } \\
\text { the academic setting }\end{array}$} & \multicolumn{2}{|c|}{ Total } & \multicolumn{2}{|c|}{ Men } & \multicolumn{2}{|c|}{ Women } & \multicolumn{2}{|c|}{$\begin{array}{l}\text { Difference of } \\
\text { means }\end{array}$} \\
\hline & $\begin{array}{c}\text { Mea } \\
\mathrm{n}\end{array}$ & SD & $\begin{array}{c}\text { Mea } \\
\mathrm{n}\end{array}$ & SD & $\begin{array}{c}\text { Mea } \\
\mathrm{n}\end{array}$ & SD & $\mathrm{t}$ & $P$ \\
\hline $\begin{array}{l}\text { Breaks rules set by the } \\
\text { school on the use of } \\
\text { technologies }\end{array}$ & 2.27 & $\begin{array}{r}1.42 \\
3\end{array}$ & 2.16 & $\begin{array}{r}1.26 \\
2\end{array}$ & 2.33 & $\begin{array}{r}1.50 \\
3\end{array}$ & $\begin{array}{r}-0.8 \\
85\end{array}$ & .377 \\
\hline Has been reprimanded & 2.19 & $\begin{array}{r}1.45 \\
2\end{array}$ & 2.12 & $\begin{array}{r}1.42 \\
6\end{array}$ & 2.24 & $\begin{array}{r}1.46 \\
8\end{array}$ & $\begin{array}{r}-0.6 \\
12\end{array}$ & .541 \\
\hline $\begin{array}{l}\text { Their grades have fa- } \\
\text { Ilen }\end{array}$ & 2.59 & $\begin{array}{r}1.58 \\
7\end{array}$ & 2.50 & $\begin{array}{r}1.47 \\
7\end{array}$ & 2.63 & $\begin{array}{r}1.64 \\
3\end{array}$ & $\begin{array}{r}-0.6 \\
33\end{array}$ & .527 \\
\hline $\begin{array}{l}\text { It is harder for them to } \\
\text { concentrate on their } \\
\text { studies }\end{array}$ & 2.81 & $\begin{array}{r}1.51 \\
4\end{array}$ & 2.74 & $\begin{array}{r}1.39 \\
8\end{array}$ & 2.85 & $\begin{array}{r}1.57 \\
2\end{array}$ & $\begin{array}{r}-0.5 \\
43\end{array}$ & .587 \\
\hline Fails to do homework & 2.63 & $\begin{array}{r}1.47 \\
0\end{array}$ & 2.58 & $\begin{array}{r}1.36 \\
6\end{array}$ & 2.66 & $\begin{array}{r}1.52 \\
4\end{array}$ & $\begin{array}{r}-0.4 \\
48\end{array}$ & .654 \\
\hline Skips class & 2.01 & $\begin{array}{r}1.37 \\
4\end{array}$ & 1.89 & $\begin{array}{r}1.17 \\
5\end{array}$ & 2.07 & $\begin{array}{r}1.46 \\
6\end{array}$ & $\begin{array}{r}-1.0 \\
09\end{array}$ & .314 \\
\hline
\end{tabular}




\begin{tabular}{|l|r|r|r|r|r|r|r|r|}
\hline $\begin{array}{l}\text { Lost their desire to } \\
\text { study }\end{array}$ & 2.72 & 1.58 & 2.49 & 1.41 & 2.84 & 1.65 & -1.7 & 9 \\
\hline $\begin{array}{l}\text { Does not interact with } \\
\text { classmates }\end{array}$ & 1.90 & $\begin{array}{r}1.27 \\
8\end{array}$ & 1.88 & $\begin{array}{r}1.19 \\
2\end{array}$ & 1.90 & 1.32 & -0.1 & .080 \\
\hline
\end{tabular}

Table 7. The influence of ICT in the academic setting

In order to ascertain the relationship between ICT usage habits (understood at this time as the activities carried out with the use of ICT) and their influence on the management of emotions, in their social sphere and in the academic setting, a bivariate Pearson Correlation was applied, transforming these four dimensions into study variables (see table 8). The results obtained show that consumption habits correlate directly and significantly with the social setting and with the academic setting of the students, not with their emotional management. It is significant to see how emotional management directly affects the use of ICTs in academic and social settings.

\begin{tabular}{|l|r|r|r|r|}
\hline $\begin{array}{l}\text { Analysis di- } \\
\text { mensions }\end{array}$ & Usage habits & Emotional management & Social setting & Academic setting \\
\hline Usage habits & 1 & 1 & & \\
\hline $\begin{array}{l}\text { Emotional ma- } \\
\text { nagement }\end{array}$ & .137 & $.456 * *$ & 1 & \\
\hline $\begin{array}{l}\text { Social } \\
\text { setting }\end{array}$ & $.372 * *$ & $.422^{* *}$ & $.510^{* *}$ & \\
\hline $\begin{array}{l}\text { Academic set- } \\
\text { ting }\end{array}$ & $.281^{* *}$ & 1 & \\
\hline
\end{tabular}

Table 8. Bivariate correlations between the analysis dimensions

Note: ** Correlation is significant at level. 01

This relationship of interdependence between the different elements evaluated implies the need to establish an effective measure to determine their behaviour, so a multiple linear regression study has been applied, which quantifies the relationship between a criterion variable $(Y=$ consumption habits) and a set of predictive variables ( $X_{1}=$ emotional management, $X_{2}=$ influence of ICTs in the social setting and $X_{3}=$ influence of ICTs in the academic setting), introduced by means of the stepwise method. The results obtained (see Table 9) highlight that of the three predictive variables incorporated into the model, one of them, the "influence of ICTs in the social setting", explains $14.8 \%$ of the total variance of the criterion. This implies that ICT usage habits directly affect the interpersonal relationships of the students but are less significant in the management of their emotions and in the school setting.

\begin{tabular}{|c|c|c|c|c|c|c|c|}
\hline Steps & $\begin{array}{c}\text { Criterion } \\
\text { variable }\end{array}$ & $\begin{array}{c}\text { Predictor } \\
\text { variables }\end{array}$ & $\mathrm{R}$ & $\mathrm{R}^{2}$ & $\begin{array}{c}\text { Delta } \\
\mathrm{R}\end{array}$ & $\mathrm{F}$ & $\mathrm{P}$ \\
\hline 1 & $\mathrm{Y}$ & $\mathrm{X}_{2}$ & .385 & .148 & .148 & 20.481 & .000 \\
\hline
\end{tabular}

Table 9. Bivariate correlations between the analysis dimensions

These data confirm the information that these families have provided when asked freely about their opinion regarding these students' use of ICT. The answers obtained have been categorised as per Table 10, where opinions focus on these students spending so much time using technology-based tools that they have less time for other tasks, both household chores and homework. They identify 
a second negative effect, a lack of direct communication with other people, which directly affects their interpersonal relationships and, to some extent, isolates them from their family and peer groups. It should also be noted that these young people are constantly exposing their personal life on the web, often without filters, thereby escaping from reality. Their impact in the academic sphere is not perceived as relevant by the families who participated in this study.

\begin{tabular}{|l|c|c|}
\hline \multicolumn{1}{|c|}{ Family perception regarding students' use of ICTs. } & $\mathrm{f}$ & $\%$ \\
\hline Takes time away from other tasks & 34 & 13.4 \\
\hline Lack of direct communication & 32 & 12.6 \\
\hline $\begin{array}{l}\text { Excessive use of mobile, social media, and games } \\
\text { console }\end{array}$ & 30 & 11.8 \\
\hline Exposure of personal life & 17 & 6.7 \\
\hline Used as a means to escape reality & 14 & 5.5 \\
\hline Family and social isolation & 8 & 3.2 \\
\hline Interference in the academic field & 2 & 0.8 \\
\hline
\end{tabular}

Table 10. Students' use of ICTs

Note: The percentage was calculated based on the value $\mathrm{N}=253$

\section{Discussion and Conclusions}

The purpose of this study was to describe the effects of ICT usage habits in the adolescent population aged 14 and 16, from the perspective of their families, and to analyse the consequences of these behaviours on their emotional management, as well as on their immediate surroundings, namely their social and academic settings. One of the most widespread habits among adolescents identified by their families is the use of technological devices, with an average of 3-4 hours a day, and even as much as 5 hours in the most extreme cases. These figures confirm data from MuñozMiralles et al. (2014), who indicate that the adolescent population spends an average of 2 or 3 hours a day using technology-based tools. In view of this situation, the OECD (2015) recommends that the average use of these technologies should be between two and three hours. As for the most widely used devices, families indicate that teenagers prefer their mobile phone and computer. In this regard, Garotte-Rojas, Jiménez-Fernández and Gómez-Barreto (2018) conclude that the young population spends more than 5 hours a day on their mobile phone, and approximately $70 \%$ have reported behavioural problems due to excessive use of this device.

Technology is present in the family homes of teenagers in our country; however, the different devices, such as mobile phones, computers, tablets, etc., are used by this population individually for the most part, with ICT usage in the company of peer groups and classmates taking on a more secondary role. These results are consistent with the findings of Pérez, Godoy and Piñero (2019), confirming that $75.4 \%$ of the adolescents in the study sample use technologies alone. Strikingly, these same authors highlight that $12.3 \%$ do not regularly engage in activities if they are not mediated by technological devices or by the use of the Internet expressly, stating that they have friends on social media they do not know personally. The activities they typically engage in are based on instant messaging and participating in or looking at social media, as indicated by participating families. This is confirmed by the data provided in the INE report (2020), which specifies that the main activities carried out by adolescents with ICT are related to the use of instant messaging such as WhatsApp, searching for information on goods and services, and making video calls through the 
internet. Likewise, Espinel-Rubio, Hernández-Suárez and Rojas-Suárez (2020b) claim that ICTs are part of teenage life, using them primarily as a mechanism to interact with others, along with searching for information. The eruption of technologies in the life of Spanish households may herald a future development of abusive behaviour patterns if "in problematic cases there are people who can live on the Internet and become prisoners of the web" (Echeburúa and Requens, 2012, p. 50). This situation is usually related to the hyper-connection of people in any sphere, including the family setting. These actions can become problematic, directly affecting emotional management in teenagers since, in the view of their families, they become irritable, mainly when their ICT usage is controlled, although they do not become aggressive or express fear of being without devices, because their objective is to relate to others. In this regard, Espinel-Rubio, Hernández-Suárez and Rojas-Suárez (2020b) claim that ICTs influence the mood of the adolescent population; specifically, they express negative feelings such as anger, sadness or demotivation when a technological device is taken away from them, mainly their mobile phone. However, they consider that this action does not interfere with their social interaction.

With regard to teenagers' social environment and their use of ICTs, the assessment given by families shows that the use of technology by minors is not harmful to their interpersonal relationships, since they do not enjoy virtual relationships any more than real world ones, and they are not left overly vulnerable by expressing their emotions in the virtual world, since they can express and communicate with ease and fluency in the physical world as well. These circumstances are confirmed by Torrecillas-Lacave, Vázquez-Barrio, Monteagudo-Barandalla (2017), arguing that, for the family, technological advancement is positive in preparing adolescents to use technologies with ease in their professional future and, in addition, they also allow for new scenarios of communication, both family and social, associated with hyper-connectedness, such as the WhatsApp application. Similarly, within the family, this regular connection causes fears associated with the inappropriate use of social media, contact pages and the possibility of viewing inappropriate content; for this reason, within the family, parental control strategies should be considered in areas such as content, timetables, and the amount of time devices may be used in order to avoid problematic usage.

With regard to engagement with ICT in the academic setting, the results show that teenagers' use of these technologies does not, in general, affect their academic activity. The only changes noted are in relation to concentration, the desire to study and do homework, actions that may interfere with their final grades. These data are confirmed by Haddon and Vicent (2014), who find that the main consequences of ICT use in classrooms are class distractions and reduced study time, causing a decline in the academic performance of teenagers who intensively use technologies and the devices and tools at their disposal, also confirmed by the work of Muñoz-Miralles et al. (2014). In contrast, there are some conclusive studies that confirm that the use of ICT in schools, for educational purposes, enhances the motivation and academic performance of students (Huertas and Pantoja, 2016).

Based on the observations discussed so far, in the results of the research carried out, ICT usage habits correlate with the family and academic settings, and not with emotional management, establishing, therefore, that emotional management affects the use of ICT but not consumption habits. In short, an empirical measure has been found, showing that, according to the families, ICT consumption habits have a direct impact on the interpersonal relationships of their children. All these circumstances demonstrate that the family setting must be attentive to the actions of teenagers to prevent the problematic effects of technology usage, because conflicts can occur in the family and in their immediate social environment (Diaz-Vicar, Mercader and Gairín, 2019).

Ultimately, technologies are here to stay and occupy a space in our professional, academic, and personal lives. However, warning bells begin to sound when, within the family setting, teenagers are seen to spend more than 3 hours a day using technological devices such as mobile phones, 
computers, tablets, etc., in order to use instant messaging, social media, or search for information as strategies of interaction, socialisation, and entertainment, in which case it is identified as problematic usage. Fear creeps in as we observe actions in adolescents such as distraction in the performance of tasks, a decline in grades, virtual interaction with other people, irritability, social or family isolation, anger and fear of being without their devices, among others; hence, the use of ICTs poses difficulties in these children's social and academic settings, as well as in their emotional management. In addition, mothers more than fathers tend to observe emotional changes in their children when technology is involved, resulting from the intensive use of ICTs. For this reason, families must initiate preventive actions in order to reduce the risks arising from the use of ICTs and the consumption habits of technologies associated with them, for example parental control over the number of hours children can use their devices to work on educational tasks.

The work presented in this paper is far from complete, since effective academic-family intervention will entail triangulating this information with data obtained from the perceptions of teenagers themselves. We need to understand, therefore, why the teenage population consumes technology and the effects this has on the decision-making processes that will define their future as citizens.

\section{References}

Carbonell, X., and Oberst, U. (2015). Las redes sociales en línea no son adictivas. Aloma: Revista de Psicología, Ciències de l'Educació i de l'Esport, 33(2), 13-19.

Cía, A.H (2013). Las adicciones no relacionadas a sustancias (dsm-5, apa, 2013): un primer paso hacia la inclusión de las adicciones conductuales en las clasificaciones categoriales vigentes. Revista de NeuroPsiquiatría, 76(4), 211.

De la Calle, M. and Muñoz, M. J. (2018). Hikikomori: el síndrome de aislamiento social juvenil. Revista de la Asociación Española de Neuropsiquiatría, 38(133), 115-129.

De la Fuente, R. (2011). Uso y abuso de las TIC en jóvenes escolarizados. Comunicación y pedagogía: Nuevas tecnologías y recursos didácticos, 250, 15-19.

De la Villa, M. and Fernández, S. (2019). Uso problemático de internet en adolescentes españoles y su relación con autoestima e impulsividad. Avances en Psicología Latinoamericana, 37(1), 103-119. Doi: http:// dx.doi. org/10.12804/revistas.urosario.edu.co/apl/a.5029

Díaz-Vicario, A., Mercader, C. and Gairín, J. (2019). Uso problemático de las TIC en adolescentes. Revista Electrónica de Investigación educativa, 21(e07), 1-11. https://doi.org/10.24320/redie.2019.21.e07.1882

Echeburúa, E (2012). Factores de riesgo y factores de protección en la adicción a las nuevas tecnologías y redes sociales en jóvenes y adolescentes. Revista Española de Drogodependencias, 37(4), 435-447.

Echeburúa, E. and Requens, A. (2012). Adicción a las redes sociales y nuevas tecnologías en niños y adolescentes. Guía para educadores. Pirámide.

Espinel-Rubio, G.A., Hernández-Suárez, C.A. and Rojas-Suárez, J. P. (2020A). Las TIC como medio socio-relacional: un análisis descriptivo en el contexto escolar con adolescentes de educación media. Revista de Investigación, Desarrollo e Innovación, 11(1), 99-112. https://doi.org/ 10.19053/20278306.v11.n1.2020.11686

Espinel-Rubio, G.A., Hernández-Suárez, C.A. and Rojas-Suárez, J.P. (2020a). Usos, apropiaciones y nuevas prácticas comunicativas de los usuarios adolescentes de Facebook. Saber, Ciencia y Libertad, 15(1), 280-296. https://doi.org/10.18041/2382-3240/saber.2020v15n1.6316

Garotte-Rojas, D., Jiménez-Fernández, S. and Gómez-Barreto, IM. (2018). Problemas derivados del uso de internet y el teléfono móvil en estudiantes universitarios. Formación Universitaria, 11(2),99-108. http:// dx.doi.org/10.4067/S0718-50062018000200099

Haddon, L. and Vincent, J. (Ed.) (2014). European children and their carers' understanding of use, risks and safety issues relating to convergent mobile media. Milán: Unicatt. 
Hernández y Hernández, D. López, R. and Salado, L.I. (2020). Educación digital y jóvenes universitarios. Edmetic, $9(2), 1-3$.

Hernández, R., Fernández, C. and Baptista, P. (2014). Metodología de la investigación. Sexta edición. México: Mc-Graw-Hill.

Huertas, A. and Pantoja, A. (2016). Efectos de un programa educativo basado en el uso de las TIC sobre el rendimiento académico y la motivación del alumnado en la asignatura de tecnología de educación secundaria. Educación XX1, 19(2), 229-250. http://doi.org/10.5944/educxx1.16464

Instituto Nacional de Estadística (2020). Equipamiento y uso de TIC en los hogares. Año 2020. https://www.i$\mathrm{n}$ e. e s / d y $\mathrm{n} \mathrm{s} / \mathrm{I} \mathrm{N}$ b a s e / e s/o p e r a c i o n. $\mathrm{h} \mathrm{t}$ ? c=estadistica_C\&cid $=1254736176741 \&$ menu $=$ ultiDatos\&idp $=1254735976608$

Muñoz-Miralles, R., Ortega-González, R., Batalla-Martínez, C., López-Moron, M. R., Manresa, J. M., and ToránMonserrat, P. (2014). Acceso y uso de nuevas tecnologías entre los jóvenes de educación secundaria, implicaciones de salud. Estudio JOITIC. Atención Primaria, 46(2), 77-88.

Neuman, W. L. (2014). Social Research Methods: Qualitative and Quantitative Approaches. Essex: Pearson.

Oliva, A., Hidalgo, M.V., Moreno, C., Jiménez García, L. Jiménez Iglesias, A., Antolín, L. and Ramos, P. (2012). Uso y riesgo de adicciones a las nuevas tecnologías entre adolescentes y jóvenes andaluces. Sevilla: Aguaclara.

Organización para la Cooperación y el Desarrollos Económicos (2015). Students, Computers and Learning: Making the Connection. http://dx.doi.org/10.1787/9789264239555-en

Pedrero-Pérez, E.J., Ruiz-Sánchez de León, M.J., Rojo-Mota, G.,Llanero-Luque, M., Pedrero-Aguilar, J., MoralesAlonso, S. and Puerta-Garcia, C. (2018). Tecnologias de la Informacion y la Comunicacion (TIC): uso problematico de Internet, videojuegos, telefonos moviles, mensajeria instantanea y redes sociales mediante el MULTICAGE-TIC. Adicciones, 30(1), 19-32.

Perez, T., Godoy, C. and Piñero, E. (2019). Hábitos de consumo de las nuevas tecnologías en adolescentes ¿uso o abuso?. European Journal of Child Development, Education and Psychopathology, 7(1), 47-57.

Puerta-Cortés, D.X. and Carbonell, X. (2014). El modelo de los cinco grandes factroes de personalidad y el uso problemático de internet en jóvenes colombianos. Adicciones, 26(1), 54-61.

Sabater, C., \& Bingen, J. (2015). Estereotipos de género y uso de las nuevas tecnologías. Icono 14(13), 208-246. Doi: http://dx.doi.org/10.7195/ ri14.v13i1.722

Sánchez-Carbonell, X., Beranuy, M., Castellana, M., Chamarro, A. and Oberst, U. (2008). Adicción a Internet y móvil: ¿Moda o trastorno? Adicciones, 20(2), 149-160.

Torrecillas-Lacave, T., Vázquez-Barrio, T. and Monteagudo-Barandalla, L.. (2017). Percepción de los padres sobre el empoderamiento digital de las familias en los hogares hiperconectados. El profesional de la información, 26(1), 97-104. 